University of Nebraska - Lincoln

DigitalCommons@University of Nebraska - Lincoln

\title{
Systematics of lochrominae (Solanaceae): Patterns in Floral Diversity and Interspecific Crossability
}

\author{
Stacey DeWitt Smith \\ University of Nebraska - Lincoln, ssmith19@unl.edu \\ David A. Baum \\ University of Wisconsin - Madison, dbaum@wisc.edu
}

Follow this and additional works at: https://digitalcommons.unl.edu/bioscifacpub

Part of the Life Sciences Commons

Smith, Stacey DeWitt and Baum, David A., "Systematics of lochrominae (Solanaceae): Patterns in Floral Diversity and Interspecific Crossability" (2007). Faculty Publications in the Biological Sciences. 133. https://digitalcommons.unl.edu/bioscifacpub/133

This Article is brought to you for free and open access by the Papers in the Biological Sciences at DigitalCommons@University of Nebraska - Lincoln. It has been accepted for inclusion in Faculty Publications in the Biological Sciences by an authorized administrator of DigitalCommons@University of Nebraska - Lincoln. 
Published in Acta Horticulturae (2007) 745: 241-254. VIth International Solanaceae Conference (ISHS 2007, held in

Madison, Wisconsin, 2006), editors: D.M. Spooner et al.Copyright (C 2007 International Society for Horticultural

Science. Used by permission.

\title{
Systematics of Iochrominae (Solanaceae): Patterns in Floral Diversity and Interspecific Crossability
}

\author{
Stacey DeWitt Smith† and David A. Baum \\ Department of Botany, University of Wisconsin-Madison, Madison, Wisconsin, USA \\ †Current address: School of Biological Sciences, University of Nebraska-Lincoln, Lincoln, Nebraska, USA
}

\begin{abstract}
Iochrominae is a florally diverse clade of 34 Andean species and six traditionally recognized genera within Physaleae. Recent phylogenetic estimates suggest that four of the six traditional genera of Iochrominae are not monophyletic. Using this phylogenetic framework, we examine the evolution of floral morphology and interspecific crossability in Iochrominae. Iochrominae is inferred to have had ancestrally a purple corolla, but now manifests a wide range of colors (red/orange, yellow, green, purple or white), several of which appear to have arisen multiple times. Other floral traits traditionally employed in taxonomy, including corolla shape, corolla length, and stapet form, are similarly evolutionarily labile and homoplasious within Iochrominae. To explore the extent of post-pollination reproductive isolation in the group and assess the potential for hybridization in nature, we conducted greenhouse crosses among seven species of Iochrominae representing five traditional genera. Of 21 reciprocal pairwise crosses, only two failed to yield viable seed. While the crossability index (a measure of successful seed set and germination) varied among crosses, it correlated only loosely with degree of relatedness. These results suggest that the speciation and diversification of Iochrominae has not been accompanied by the formation of strong barriers to pollen receipt or early seed maturation. However, pre-mating factors, such as allopatry and ethological isolation, and post-germination factors, such as reduced hybrid fitness, might have together acted to maintain the morphological and evolutionary cohesiveness of Iochrominae species.
\end{abstract}

Keywords: Flower color, Hybridization, Incompatibility, Phylogeny, Physaleae, Sympatry

\section{Introduction}

For groups in which the taxonomy has been based on morphological characters of possible adaptive significance, such as flower form and vegetative habit, molecular phylogenies permit the independent assessment of relationships and the identification of instances of convergent evolution (Givnish, 1997). This paper focuses on Iochrominae sensu Olmstead et al. (1999), a group of Andean Solanaceae whose evolutionary history has recently been clarified using DNA sequence data from three nuclear regions (Smith and Baum, 2006). Using this phylogenetic framework, we here examine the evolution of taxonomically important floral traits and evaluate the potential for hybridization among species distributed across the clade.

The diversity of floral morphologies within Iochrominae has lead to the recognition of six genera: Acnistus Schott, Dunalia H.B.K, Eriolarynx (Hunz.) Hunz., Iochroma Benth., Saracha R.\&P. and Vassobia 
Rusby. Acnistus contains a single species, A. arborescens, a treelet with small, fragrant, white flowers with yellow-green markings inside the corolla lobes (Hunziker, 2001). Dunalia includes five tubularflowered species diagnosed by a prominently winged or toothed stapet (stamen-petal tissue at the point of filament insertion), (Hunziker, 1960). The three species of Eriolarynx are distinguished by campanulate corollas with a dense ring of hairs inside (Hunziker, 2000). Iochroma, the largest genus, has approximately 25 species characterized by showy, colorful, tubular flowers (Shaw, 1998). Saracha contains two species with yellow-purple, campanulate to funnel-shaped flowers, restricted to the high elevation páramos (Alvarez, 1996). Vassobia is a genus of two species with glabrous campanulate or rotate corollas (Hunziker, 2001).

Molecular phylogenetic analysis has suggested that these traditional, morphologically delimited genera are largely unnatural groupings. Combined phylogenetic analyses from three nuclear loci, the internal transcribed spacer (ITS), the second intron of LEAFY, and exons 2 to 9 of GBSSI, show that all of the traditional genera, with the exception of Vassobia and the monotypic Acnistus, are not monophyletic (Figure 1; Smith and Baum, 2006). Accordingly, many of the floral characters used to delimit groups appear to be homoplasious. In this contribution, we examine the evolution of four floral traits that have been important in taxonomic studies: flower color, corolla shape, corolla length, and stapet morphology. By mapping changes in these traits onto the independently derived molecular phylogeny, we identify instances of convergence.

Our second objective is to evaluate the potential for hybridization among groups of Iochrominae based on controlled greenhouse crosses. The occurrence of hybridization in the wild has long been noted by collectors and taxonomists (Shaw, 1998; Smith, 2006). Smith and Baum (2006) identified three putative hybrid taxa based on morphological features, geographic distribution, and conflicting position in nuclear gene phylogenies. In each instance, parental taxa were not each other's closest relatives, suggesting wide crossability among members of Iochrominae. Here we investigate crossability in Iochrominae in more detail by selecting species from across the phylogeny and conducting controlled crosses. This survey of crossability provides an initial estimate of the potential for gene flow among lineages, which is particularly relevant given the frequent co-occurrence of Iochrominae species in some regions of the Andes.

\section{Materials And Methods}

\section{Floral Trait Reconstruction}

Four floral characters were chosen for trait reconstruction: flower color, corolla shape, corolla length and stapet morphology. Flower color states reflect the dominant color of the corolla. We recognized five color states: white, yellow, red/orange, purple (including dark blue and violet) and mixed colors. Species were only coded as mixed colors (e.g., green and purple) when both colors were prominent throughout the corolla, as in Saracha punctata, which has yellow petals with purple punctuations (spots) from base to apex. Corolla shape and stapet morphology were coded using descriptions in taxonomic treatments (Hunziker, 1960, 2001; Alvarez, 1996; Shaw, 1998) and a previous morphological analysis (Sawyer, 2005). In coding corolla length, we divided the continuum into three classes: small $(0-2 \mathrm{~cm})$, intermediate $(2-4 \mathrm{~cm})$ and large (over $4 \mathrm{~cm})$. Taxa were classed using the midpoint of the range listed in species descriptions. However, for three taxa (Iochroma cf. peruvianum, I. sp. nov. "tingoense" and I. sp. nov.), this information was not available; thus, corolla length was coded from examination of herbarium collections in the University of Wisconsin herbarium (WIS).

Ingroup taxa included all species of Iochrominae sampled by Smith and Baum (2006) except for three putative hybrid taxa (Iochroma ayabacense, I. stenanthum and I. sp. nov. "sagasteguii"). Six outgroup taxa from Physaleae were included: Physalis peruviana, Cuatresia harlingiana, Larnax sachapapa, Leucophysalis grandiflora, Tubocapsicum anomalum and Witheringia solanacea. Character states were traced using MacClade 4.0 (Maddison and Maddison, 2000) onto the maximum likelihood topology 
from combined analyses of ITS, LFY, and GBSSI (Smith and Baum, 2006). All characters were treated as unordered, and gains and losses of character states were equally weighted.

\section{Crossing Studies}

The seven species of Iochrominae selected for crossing studies are listed in Table 1. Our selection aimed to capture a range of phylogenetic relatedness, from sister species (e.g., Eriolarynx lorentzii and Iochroma australe) to distantly related species (e.g., Acnistus arborescens and Vassobia breviflora), and to sample the breadth of morphological variation that has resulted in the recognition of six traditional genera in this clade. Published chromosome counts for Iochrominae suggest that all are diploid, with $n=12$ (Hunziker, 2001 and references therein).

Surveys of breeding systems in Solanaceae have not included Iochrominae, but its relatives in Physaleae are predominantly self-incompatible (Igic et al., 2006). As a first attempt to document breeding systems in Iochrominae, we conducted intraspecific pollinations with both self and cross pollen to determine if the species are indeed self-incompatible. Also, we monitored flowers that were not pollinated to test for selfing. A minimum of 15 flowers were subject to each of three treatments (self pollen, homospecific cross pollen, and no pollen) and multiple plants, up to five, were used for each species when possible.

Species that appeared to be self-compatible based on these data (i.e., those in which self pollen or no pollen resulted in fruit set) were emasculated in bud before conducting interspecific crosses. For self-incompatible species, interspecies crosses were conducted on intact flowers. Forty-two reciprocal pairwise interspecific crosses among the seven study species were performed, with 10 to 25 pollinations for each pair.

Pollinations were accomplished by tapping a mature anther over the stigma of a receptive firstday flower. The resulting dusting of pollen on the stigmatic surface was visible with the naked eye. To minimize the risk of pollen contamination, all experiments took place in insect-free greenhouses (Walnut Street facility at the University of Wisconsin-Madison). Calyces of pollinated flowers were marked with a black permanent marker and tagged with the treatment type and date with jeweler's tags. Iochrominae fruits mature in three to five weeks, depending on species. If mature fruits were formed, they were collected and their seeds were extracted and counted. Empty seeds (which float to the surface during washing) were discarded. To assess germinability, seeds were placed on moist filter paper in Petri dishes at room temperature. After five weeks, seeds that had not germinated were considered inviable.

We examined how interspecific crossability varies with relatedness. We computed patristic distances (sum of the lengths of all intervening branches) for each pair of taxa using the combined LFY, GBSSI, and ITS maximum likelihood analysis (Smith and Baum, 2006). A composite measure of crossability, the product of relative seed set and seed viability, was plotted against patristic distances. Linear regression analysis, conducted in MS Excel, was used to determine the significance of the relationship. We recognize that, because these species are not independent, but related through a phylogeny, statistical analyses should formally take account of shared history (e.g., Moyle et al., 2004). Thus, the analysis presented here should be considered only a preliminary assessment of the relationship between crossability and phylogenetic distance with inflated degrees of freedom.

\section{Results}

\section{Trait Reconstruction}

Figure 1 shows the inferred patterns of evolution of flower color, corolla shape, corolla length and stapet morphology in Iochrominae. Branches are colored to show the state inferred for that lineage, and the state for each taxon is shown in a box at each branch tip. 
Purple flowers appeared to be ancestral in Iochrominae (Figure 1). Other colors showed multiple independent origins. Red and white flowers each appeared to have arisen independently in two lineages and yellow flowers in three lineages. Species with mixed flower colors, such as yellow petals with purple markings, have arisen in two lineages. The color changes are concentrated in the mainly Iochroma clade (the smallest clade containing I. calycinum and I. cf. peruvianium). It is notable that loss of purple in Iochrominae appears irreversible; that is, none of the lineages that have switched from purple to other colors have later regained purple.

Corolla shape also appeared to have undergone convergent evolution, although given the distribution of character states, the ancestral flower form in Iochrominae and the total number of switches to other forms remains unclear. Looking just within the mainly Iochroma clade, it appeared that at least two lineages have moved from funnel-shaped to tubular flowers. Within the Dunalia + Eriolarynx + Saracha + Vassobia clade, tubular flowers are most common, but the frequent appearance of other forms (rotate, campanulate, funnel-shaped and salverform) precluded trait reconstruction along the backbone of the clade.

Changes in corolla length could not be reconstructed unequivocally at the base of Iochrominae, resulting in ambiguity in the ancestral state for the clade and in the polarity of subsequent evolution. However, the outgroups are characterized by short corollas $(0-2 \mathrm{~cm})$ while most Iochrominae have larger corollas $(2-4 \mathrm{~cm})$, suggesting an overall increase in length early in the evolution of the group. Within the clade, instances of corolla tube reduction (as in Acnistus arborescens) and elongation (as in Iochroma calcyinum) have clearly occurred multiple times.

The tissue joining the filament base to the corolla, the "stapet," shows substantial morphological variation in Iochrominae, and has been used in prior taxonomic treatments to distinguish Dunalia from allied genera. Examining the evolution of the stapet in the context of this independently derived phylogeny suggests that changes in stapet morphology are frequent and homoplasious, particularly in the Dunalia + Eriolarynx + Saracha + Vassobia clade. Thus, the prominently toothed or winged stapet does not appear as taxonomically significant as previously thought (Hunziker, 1960).

\section{Intraspecific Crosses}

Five of the seven species were self-incompatible, producing fruit only when pollinated with pollen from another individual. The two remaining species, Acnistus arborescens and Vassobia breviflora, appeared to be at least partly self-compatible, setting some seed when pollinated with self pollen (mean $=4.2$ and 5.9 per cross, or $17 \%$ and $16 \%$ of the seed set from crosses, respectively) and setting a few seed with no hand pollination (mean $=0.2$ and 2.2 per cross, respectively). Average success in terms of fruit set, seed production, and seed viability are given in Table 1. Percent fruit set is the proportion of pollinations that resulted in mature fruit. The percent fruit set was multiplied by the average number of seeds per fruit to give the actual seed set (see McDade and Lundberg, 1982).

\section{Interspecific Crosses}

Many interspecific crosses resulted in fruit set, seed set, and germination success comparable to that of intraspecific crosses. The actual seed set was compared between intra- and interspecific crosses to provide a crossability index (Table 2). Only a few crosses resulted in total failure to produce seed. Vassobia breviflora pollen failed to yield fruit when used to pollinate Eriolarynx lorentzii, Iochroma cyaneum, and I. gesnerioides, and I. cyaneum also did not produce fruit when pollinated with Acnistus arborescens or Dunalia brachyacantha pollen (Table 2A). For several crosses, percent fruit set was actually higher in interspecific crosses than in intraspecific crosses (Table 2A). However, all but two crosses $(E$. lorentzii $\times I$. australe and A. arborescens $\times V$. breviflora $)$ had fewer seeds per fruit in interspecific crosses (Table 2B). Some fruit from interspecific crosses had only empty seeds or minute seeds not much larger than ovules (S.D. Smith, pers. obs.); these seeds were discarded during clean- 
ing and the average fruit set was recorded as zero. Several crosses (e.g., I. australe $\times$ D. brachyacantha) produced only such empty fruit.

Relative actual seed set (the ratio of the product of percent fruit set and average seed set between inter- and intraspecific crosses) is often used as a measure of crossability (e.g., McDade and Lundberg, 1982). Here this measure indicated that of 42 reciprocal crosses, all produced seed in at least one direction (Table 2C, Figure 2). Averaging relative actual seed set across both directions for each pair of species, it appeared that interspecific pollinations yield less seed than intraspecific crosses, indicating the existence of some post-pollination, pre-seed set barriers to reproduction.

We also examined the possibility that some of the seeds produced in the interspecific crosses were inviable (Table 2D). Only in crosses involving Vassobia breviflora did a significant number of seeds fail to germinate. We multiplied the percent viability by the actual seed set and compared it among interand intraspecific crosses as an additional composite measure of crossability. In only two of 21 species pairs did crosses completely fail in both directions by this measure, and these both involved $V$. breviflora (Table 2E). For the remaining pairs, interspecific crosses, in at least one direction, produced germinable seed.

Crossability, measured as the product of actual seed set and seed viability (Table 2E), appeared to decay slightly with increasing patristic distance (Figure 3$)$, but the regression was not significant $\left(\mathrm{R}^{2}\right.$ $=0.071, P=0.244, \mathrm{df}=20$ ). This analysis ignores dependence among data points due to shared phylogenetic history.

\section{Conclusions}

\section{Floral Trait Evolution}

Relative to closely allied taxa such as Physalis and Witheringia, Iochrominae displays a great diversity of flower colors, sizes, and shapes. Not only do character states that are absent or uncommon in related taxa, such as red coloration or a tubular form, occur in Iochrominae, but they appear to have evolved multiple times in the group. Possible explanations for the frequent evolutionary shifts in flower form and color in Iochrominae include pollinator-mediated diversifying selection and a relatively unconstrained, "evolvable" floral developmental program. Given the potential for crossing Iochrominae species differing in floral traits, it may be possible to dissect the genetic architecture underlying this floral diversity using traditional and molecular genetic approaches (e.g., QTL mapping, analysis of candidate genes).

Our study also suggests that traditional floral characters are not reliable indicators of phylogenetic relatedness in Iochrominae. While there is some general tendency for related Iochrominae species to have similar floral morphologies, the particular floral traits examined here appear too evolutionarily labile to serve individually as diagnostic characters for any major clades. For example, all members of the "umbellatum" clade (Smith and Baum, 2006) share salverform corollas, but this form also appears independently in Dunalia solanacea.

Future taxonomic work in Iochrominae might fruitfully look beyond floral characters to vegetative, anatomical, or biochemical variation. Substantial differences exist in the presence and placement of hairs and in hair type. Eriolarynx and the nested species Iochroma australe are covered in sticky glandular hairs and Dunalia solanacea has a dense pubescence of stellate hairs while Acnistus and related taxa are largely glabrous. The variation in armature may be taxonomically useful as spines are restricted to the Dunalia + Eriolarynx + Saracha + Vassobia clade (Smith and Baum, 2006). Anatomical variation has not been extensively explored in Iochrominae, aside from a study of ray cells in Saracha (Lindorf, 1999). In contrast, many biochemical studies focused on Iochroma and related genera (e.g., Lischewski et al., 1992; Alfonso et al., 1993) and have uncovered a wide variety of novel withanolides. Studies to date have examined only a few species (D. brachyacantha, I. australe, I. fuchsioides, V. breviflora), but with increased taxon sampling, these biochemical 
surveys may soon provide useful characters for classification. Variation in the presence/absence of anthocyanin and carotenoid pigments may be an additional source of biochemical characters (Smith, 2006). Integrating new morphological and biochemical characters with the phylogenetic framework, future systematic studies will be aimed at constructing a natural and more stable system of classification for Iochrominae.

\section{Breeding Systems and Crossability in Iochrominae}

Our study revealed variation in the breeding system in Iochrominae and supported wide crossability among its lineages. We found that, of the seven species examined, two (Acnistus arborescens and Vassobia breviflora) were capable of producing seed from self-pollination while the remaining five appeared to be self-incompatible. Crosses among species were largely successful with only two $(V$. breviflora $\times$ Eriolarynx lorentzii and $V$. breviflora $\times$ Iochroma cyaneum) of the 21 species pairs failing to produce viable seed in both directions (Figure 2). The evidence of failure among crosses included reduced fruit set, reduced seed set, and seed inviability. In contrast to studies in other groups (Coyne and Orr, 1989; Moyle et al., 2004), the variation in crossability among Iochrominae did not appear to be closely tied to genetic relatedness (Figure 3). In future crossing studies in Iochrominae, it would be useful to track pollen tube growth and seed development to determine if rejection occurs early (before fertilization) or late, as has been documented in other Solanaceae (Avery et al., 1959; Whalen, 1979; Bohs, 1991).

Due to the limited number of crosses completed, our results are best interpreted not as an exact quantification of crossability, but rather a demonstration that the study taxa are capable of producing viable seeds from interspecific pollination. Because we did not grow the seeds to maturity for most crosses, we cannot be sure that viable and fertile F1 plants would be formed. However, F1 seedlings from the Iochroma gesnerioides $\times$ I. cyaneum cross were grown to maturity and appeared intermediate between the parents in floral and vegetative morphology. They formed fruit with viable seed after pollination by parental plants, although all crosses using the F1 individuals as pollen donors failed, suggesting low pollen viability (data not shown). This result suggests that interspecific hybrids may develop into mature viable plants that can interbreed with parental populations.

The demonstrated potential for interspecific gene flow becomes relevant to speciation and evolution in areas where members of Iochrominae occur in sympatry. Iochrominae often co-occur, particularly in the Amotape-Huancabamba zone, a section of the Andes that straddles the border between Ecuador and Peru. Smith and Baum (2006) found genetic evidence of hybrid ancestry for three Iochroma species in this zone. For instance, I. ayabacense appeared to be a hybrid between I. cyaneum and I. squamosum, which all co-occur in the environs of Ayabaca in northern Peru.

Nonetheless, some reproductive isolation has surely arisen within Iochrominae, as many species grow in sympatry with no observed hybrid individuals. For example, in the high elevation scrub east of Trujillo, Peru, Iochroma edule, I. umbellatum and I. parvifolium occur in close proximity and occasionally in mixed stands (Smith, 2006), but no hybrid individuals have been observed. If crosses among I. edule, I. umbellatum and I. parvifolium similarly result in viable seed, as one would predict based on the general tendency towards crossability seen here, the absence of hybrids in the wild could be explained by a combination of pre-pollination isolation (e.g., phenology; differential pollinator visitation) and post-pollination mechanisms (e.g., low hybrid viability or fertility). The occurrence within Iochrominae (a group with no known chromosome number differences) of species that easily form hybrid zones and species that never hybridize even in close sympatry makes Iochrominae a potential model system for studying the maintenance of species boundaries in nature. Combined with the excellent genetic tools emerging within Solanaceae, there is great potential for field and laboratory studies of speciation using different species of Iochrominae. 
Acknowledgments - The authors thank L. Bohs and G. van der Weerden for donation of seed for crossing studies, E.L. Hummel and I. Kabera of the Walnut Street Greenhouses for technical assistance, J. Bosch, T. Mehta, N. Van Abel and K. Walsh for help with seed processing, R.A. Smith for editing, K. Elliot for assisting with artwork, the National Science Foundation (Grant DEB-0309310) for financial support, and R. Olmstead and an anonymous reviewer for helpful comments.

\section{Literature Cited}

Alfonso, D., Bernardinelli, G. and Kapetanidis, I. 1993. Withanolides from Iochroma coccineum. Phytochemistry 34: 517-521.

Alvarez, A. 1996. Systematics of Saracha (Solanaceae). Master's thesis, University of Missouri-St. Louis, USA.

Avery, A.G., Satina, S. and Rietsema, J. 1959. Blakeslee: The Genus Datura. Ronald Press, New York.

Bohs, L. 1991. Crossing studies in Cyphomandra (Solanaceae) and their systematic and evolutionary significance. Amer. J. Bot. 78: 1,683-1,693.

Coyne, J.A. and Orr, H.A. 1989. Patterns of speciation in Drosophila. Evolution 43: 362-381.

Givnish, T.J. 1997. Adaptive radiation and molecular systematics: issues and approaches. p.1-54. In: T.J. Givnish and K.J. Sytsma (editors), Molecular Evolution and Adaptive Radiation, Cambridge University Press, Cambridge.

Hunziker, A.T. 1960. Estudios sobre Solanaceae II. Sinopsis taxonómica del género Dunalia H.B.K. Bol. Acad. Nac. Cien. 51: 211-244.

Hunziker, A.T. 2000. Two novelties for the tribe Solaneae (Solanaceae). Kurtziana 28: 65-68.

Hunziker, A.T. 2001. Genera of Solanaceae. A.R.G. Ganter Verlag K.G., Konigstein, Germany.

Igic, B., Bohs, L. and Kohn, J.R. 2006. Ancient polymorphism reveals unidirectional breeding system shifts. Proc. Nat. Acad. Sci. 103: 1,359-1,363.

Lindorf, H. 1999. Perforated ray cells in Saracha quitensis (Solanaceae). IAWA Journal 20: 75-77.

Lischewski M., Hang, N.T.B., Porzel, A., Adam, G., Massiot, G. and Lavaud, C. 1992. Withanolide glycosides from Dunalia australis. Phytochemistry 31: 939-942.

Maddison, D.R. and Maddison, W.P. 2000. MacClade 4: Analysis of Phylogeny and Character Evolution. Sinauer, Sunderland, Massachusetts, USA.

McDade, L.A. and Lundberg, J.G. 1982. A new tabular and diagrammatic method for displaying artificial hybridization data, with an example from Aphelandra (Acanthaceae). Syst. Bot. 7: 13-25.

Moyle, L.C., Olson, M. and Tiffin, P.L. 2004. Patterns of reproductive isolation in three angiosperm genera. Evolution 58: 1,195-1,208.

Olmstead, R.G., Sweere, J.A., Spangler, R.E., Bohs, L. and Palmer, J.D. 1999. Phylogeny and provisional classification of the Solanaceae based on chloroplast DNA. p.111-137. In: M. Nee, D.E. Symon, R.N. Lester and J.P. Jessop (editors), Solanaceae IV: Advances in Biology and Utilization, Royal Botanic Gardens, Kew, UK.

Sawyer, N.W. 2005. Systematics of Deprea and Larnax (Solanaceae) based on morphological evidence. p.259-285. In: R.C. Keating, V.C. Hollowell and T.B. Croat (editors), A Festschrift for William G. D'Arcy: The Legacy of a Taxonomist. Monogr. Syst. Bot. Missouri Bot. Gard., Vol. 104.

Shaw, J.M.H. 1998. Iochroma: a review. New Plantsman 5: 154-191.

Smith, S.D. 2006. Floral diversification and pollination biology of the Andean clade Iochrominae (Solanaceae). 246 p. Ph.D. thesis, University of Wisconsin, Madison, USA.

Smith, S.D. and Baum, D.A. 2006. Phylogenetics of the florally diverse Andean clade Iochrominae (Solanaceae). Amer. J. Bot. 93: 1,140-1,153.

Whalen, M.D. 1979. Taxonomy of Solanum section Androceras. Gentes Herbarum 11: 359-426. 


\section{Tables}

Table 1. Self-incompatibility in Iochrominae. Generic names are abbreviated (Acnistus, Dunalia, Eriolarynx, Iochroma and Vassobia).

\begin{tabular}{|c|c|c|c|c|c|}
\hline $\begin{array}{l}\text { Taxon } \\
\text { Voucher } \\
\text { Nijmegen \#a }\end{array}$ & Treatment & $\begin{array}{l}\% \text { fruit } \\
\text { set }(n)^{b}\end{array}$ & $\begin{array}{l}\text { Average } \\
\text { no. seeds } \\
\text { per fruit }{ }^{c}\end{array}$ & $\begin{array}{l}\text { Actual } \\
\text { seed } \\
\text { set }^{\mathrm{d}}\end{array}$ & $\begin{array}{l}\text { Germination } \\
\text { success }(n)^{b}\end{array}$ \\
\hline $\begin{array}{l}\text { A. arborescens (L.) Schlecht. } \\
\text { Bohs } 2428 \text { (UT) }\end{array}$ & $\begin{array}{l}\text { cross } \\
\text { self } \\
\text { none }\end{array}$ & $\begin{array}{l}1.00(17) \\
0.88(32) \\
0.67(30)\end{array}$ & $\begin{array}{l}24.1 \pm 1.3 \\
4.8 \pm 0.5 \\
0.3 \pm 0.1\end{array}$ & $\begin{array}{l}24.1 \\
4.2 \\
0.2\end{array}$ & $\begin{array}{l}0.88(56) \\
0.53(36)\end{array}$ \\
\hline $\begin{array}{l}\text { D. brachyacantha Miers } \\
\text { Nee \& Bohs } 50811 \text { (NY) }\end{array}$ & $\begin{array}{l}\text { cross } \\
\text { self } \\
\text { none }\end{array}$ & $\begin{array}{r}0.89(46) \\
0(15) \\
0(15)\end{array}$ & $\begin{array}{l}22.1 \pm 1.9 \\
- \\
-\end{array}$ & $\begin{array}{l}19.7 \\
- \\
-\end{array}$ & $0.92(48)$ \\
\hline $\begin{array}{l}\text { E. lorentzii (Dammer) Hunz. } \\
\text { Hawkes et al. } 3452 \text { (BIRM) } \\
944750207\end{array}$ & $\begin{array}{l}\text { cross } \\
\text { self } \\
\text { none }\end{array}$ & $\begin{array}{r}0.75(32) \\
0(52) \\
0(41)\end{array}$ & $\begin{array}{l}82.1 \pm 4.5 \\
- \\
-\end{array}$ & $\begin{array}{l}61.6 \\
- \\
-\end{array}$ & $0.94(69)$ \\
\hline $\begin{array}{l}\text { I. australe Griseb. } \\
\text { Hawkes et al. } 4326 \text { (BIRM) } \\
904750145\end{array}$ & $\begin{array}{l}\text { cross } \\
\text { self } \\
\text { none }\end{array}$ & $\begin{array}{r}0.72(36) \\
0(61) \\
0(76)\end{array}$ & $\begin{array}{l}69.8 \pm 7.7 \\
- \\
-\end{array}$ & $\begin{array}{l}50.4 \\
- \\
-\end{array}$ & $0.83(64)$ \\
\hline $\begin{array}{l}\text { I. cyaneum (Lindl.) M.L. Green } \\
\text { Smith } 265 \text { (WIS) }\end{array}$ & $\begin{array}{l}\text { cross } \\
\text { self } \\
\text { none }\end{array}$ & $\begin{array}{r}0.62(53) \\
0(30) \\
0(15)\end{array}$ & $\begin{array}{l}96.9 \pm 9.1 \\
- \\
-\end{array}$ & $\begin{array}{l}60.4 \\
- \\
-\end{array}$ & $0.93(72)$ \\
\hline $\begin{array}{l}\text { I. gesnerioides Miers } \\
\text { Smith } 266 \text { (WIS) } \\
944750129\end{array}$ & $\begin{array}{l}\text { cross } \\
\text { self } \\
\text { none }\end{array}$ & $\begin{array}{r}0.57(23) \\
0(20) \\
0(17)\end{array}$ & $\begin{array}{l}91.1 \pm 9.3 \\
- \\
-\end{array}$ & $\begin{array}{l}51.5 \\
- \\
-\end{array}$ & $0.69(32)$ \\
\hline $\begin{array}{l}\text { V. breviflora (Sendt.) Hunz. } \\
\text { Smith } 262 \text { (WIS) } \\
904750332\end{array}$ & $\begin{array}{l}\text { cross } \\
\text { self } \\
\text { none }\end{array}$ & $\begin{array}{r}0.88(73) \\
0.19(104) \\
0.06(62)\end{array}$ & $\begin{array}{l}41.8 \pm 3.0 \\
30.9 \pm 5.9 \\
34.5 \pm 5.9\end{array}$ & $\begin{array}{l}36.6 \\
5.9 \\
2.2\end{array}$ & $0.71(69)$ \\
\hline
\end{tabular}

a For accessions contributed by the Solanaceae collection in Nijmegen, Netherlands, the accession numbers are given.

b Sample size $(n)$ is given for the number of pollinations completed and for the number of seeds used in germination trials.

c Average number of seeds per fruit is shown \pm one standard error.

$\mathrm{d}$ Actual seed set is the percent fruit set multiplied by the average number of seeds per fruit. 
Table 2. Reciprocal crossability of seven Iochrominae species The maternal parent is listed in the first column and the paternal parent in the top row of each table; species names are abbreviated with the first letter of the genus and the first three letters of the specific epithet (Acnistus arborescens, Dunalia brachyacantha, Eriolarynx lorentzii, Iochroma australe, I. cyaneum, I. gesnerioides, and Vassobia breviflora). In each cell, the value for the interspecific cross (Table 1 ) is divided by the value for the intraspecific cross to give a relative value. Some data are not applicable (indicated with an " $x$ "); for example, there are no seed per fruit values for crosses that failed to yield mature fruit.

A. Relative fruit set

\begin{tabular}{lllccccc}
\hline + & A. arb. & D. bra. & E. lor. & I. aus. & I. cya. & I. ges. & V. bre. \\
\hline A. arb. & 1.00 & 1.00 & 0.96 & 1.00 & 0.89 & 0.94 & 1.00 \\
D. bra. & 0.52 & 1.00 & 1.06 & 0.34 & 0.84 & 0.66 & 1.01 \\
E. lor. & 0.47 & 0.97 & 1.00 & 1.20 & 0.62 & 1.17 & 0 \\
I. aus. & 0.69 & 1.38 & 0.90 & 1.00 & 1.13 & 1.17 & 0.88 \\
I. cya. & 0 & 0 & 1.13 & 0.75 & 1.00 & 0.27 & 0 \\
I. ges. & 0.52 & 0.14 & 0.59 & 1.01 & 1.46 & 1.00 & 0 \\
V. bre. & 0.29 & 1.05 & 0.68 & 0.73 & 0.81 & 0.91 & 1.00 \\
\hline
\end{tabular}

B. Relative seeds per fruit

\begin{tabular}{lllccccc}
\hline + & A. arb. & D. bra. & E. lor. & I. aus. & I. cya. & I. ges. & V. bre. \\
\hline A. arb. & 1.00 & 0.78 & 0.87 & 0.79 & 0.59 & 0.58 & 1.03 \\
D. bra. & $\times$ & 1.00 & 0.45 & 0.42 & 0.23 & 0.52 & 0.49 \\
E. lor. & 0.46 & 0.24 & 1.00 & 1.16 & 0.51 & 0.85 & $\times$ \\
I. aus. & 0.07 & 0 & 0.38 & 1.00 & 0.56 & 0.86 & 0 \\
I. cya. & $\times$ & $\times$ & 0.60 & 0.12 & 1.00 & 0.13 & $\times$ \\
I. ges. & 0.30 & 0 & 0.12 & 0.10 & 0.11 & 1.00 & $\times$ \\
V. bre. & 0.08 & 0.25 & 0.11 & 0.13 & 0.10 & 0.21 & 1.00 \\
\hline
\end{tabular}

C. Relative actual seed set

\begin{tabular}{lllccccc}
\hline + & A. arb. & D. bra. & E. lor. & I. aus. & I. cya. & I. ges. & V. bre. \\
\hline A. arb. & 1.00 & 0.78 & 0.84 & 0.79 & 0.52 & 0.55 & 1.03 \\
D. bra. & 0 & 1.00 & 0.47 & 0.14 & 0.19 & 0.34 & 0.50 \\
E. lor. & 0.21 & 0.23 & 1.00 & 1.39 & 0.31 & 0.99 & 0 \\
I. aus. & 0.05 & 0 & 0.34 & 1.00 & 0.63 & 1.01 & 0 \\
I. cya. & 0 & 0 & 0.68 & 0.09 & 1.00 & 0.04 & 0 \\
I. ges. & 0.16 & 0 & 0.07 & 0.10 & 0.15 & 1.00 & 0 \\
V. bre. & 0.02 & 0.26 & 0.08 & 0.10 & 0.08 & 0.19 & 1.00 \\
\hline
\end{tabular}


D. Relative seed viability

\begin{tabular}{|c|c|c|c|c|c|c|c|}
\hline o & A. $a r b$. & D. bra. & E. lor. & I. aus. & I. cya. & I. ges. & V. bre. \\
\hline A. $a r b$. & 1.00 & 0.98 & 0.75 & 0.13 & 0.10 & 0.78 & 0.93 \\
\hline D. bra. & $\times$ & 1.00 & 0.75 & 0.58 & 0.10 & 0.78 & 0.49 \\
\hline E. lor. & 0.84 & 0.80 & 1.00 & 0.99 & 0.45 & 0.97 & $\times$ \\
\hline I. aus. & 0.27 & 0 & 0.98 & 1.00 & 0.60 & 0.87 & $x$ \\
\hline I. суа. & $\times$ & $x$ & 1.00 & 0.86 & 1.00 & 0.42 & $x$ \\
\hline I. ges. & 1.34 & 0 & 0.95 & 0.17 & 0.18 & 1.00 & $\times$ \\
\hline V. bre. & 0 & 0 & 0 & 0.04 & 0 & 0.68 & 1.00 \\
\hline \multicolumn{8}{|c|}{ E. Relative actual seed set * seed viability } \\
\hline & A. $a r b$. & D. bra. & E. lor. & I. aus. & I. cya. & I. ges. & V. bre. \\
\hline A. $a r b$. & 1.00 & 0.77 & 0.63 & 0.11 & 0.05 & 0.43 & 0.96 \\
\hline D. bra. & 0 & 1.00 & 0.35 & 0.08 & 0.02 & 0.27 & 0.24 \\
\hline E. lor. & 0.18 & 0.18 & 1.00 & 1.38 & 0.14 & 0.96 & 0 \\
\hline I. aus. & 0.01 & 0 & 0.33 & 1.00 & 0.38 & 0.88 & 0 \\
\hline I. cya. & 0 & 0 & 0.68 & 0.08 & 1.00 & 0.02 & 0 \\
\hline I. ges. & 0.21 & 0 & 0.07 & 0.02 & 0.03 & 1.00 & 0 \\
\hline V.bre. & 0 & 0 & 0 & $3.7 \times 10^{-3}$ & 0 & 0.13 & 1.00 \\
\hline
\end{tabular}




\section{Figures}

Flower color (unordered)

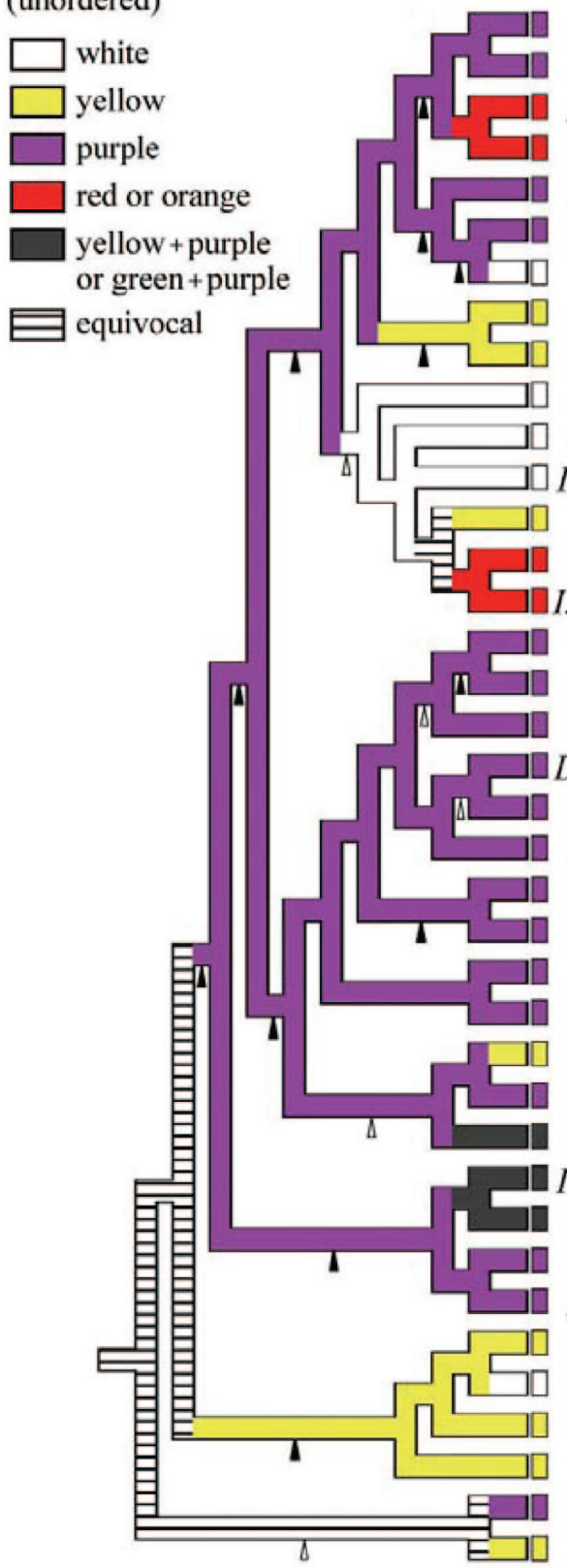

I. calycinum

I. sp. nov.

I. gesnerioides

I. fuchsioides

I. cornifolium

I. cyaneum

I. loxense

I. squamosum

I. lehmannii

I. ellipticum

A. arborescens

I. confertiflorum

I. salpoanum

I. edule

I. cf. peruviamu

E. lorentzii

I. australe

E. fasciculata

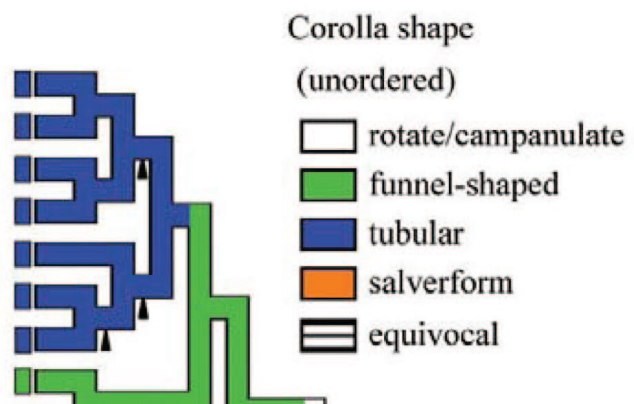

D. spinosa

I. parvifolium

V. breviflora

V. dichotoma

D.obovata

D.spathulata

D. solanacea

S. quitensis

S. punctata

sp. "tingoense"

I. umbellatum

I. nitidum

I. grandiflorum

$P$. peruviana

L. grandiflora

W. solanacea

T. anomalum

C. harlingiana

L. sachapapa

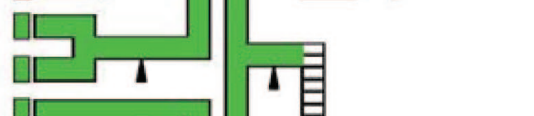


Flower length

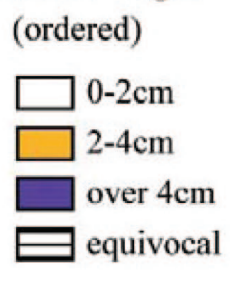

S. D. SМाTH \&в

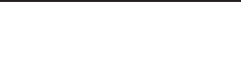




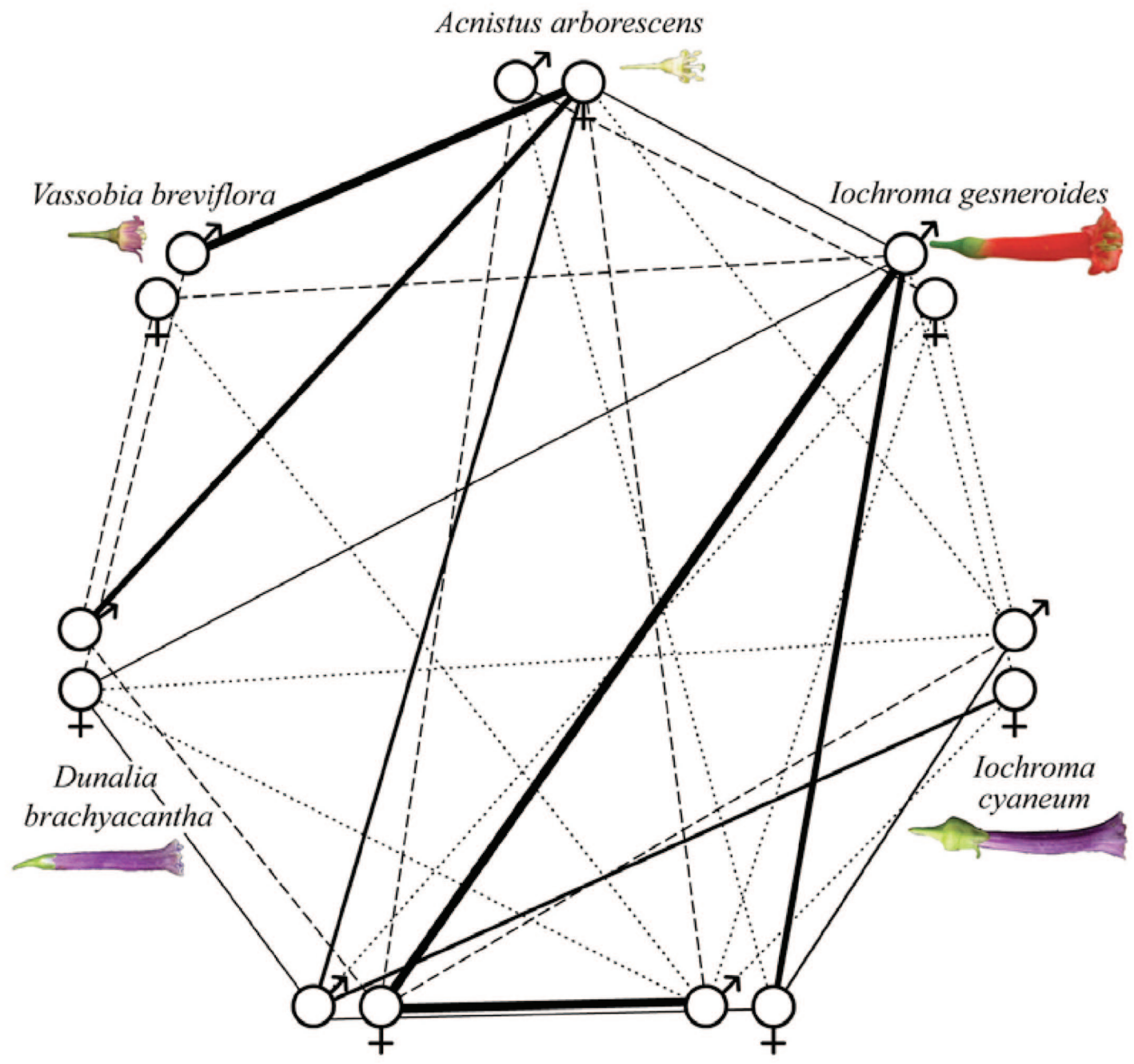

Eriolarynx lorentzii

Iochroma australe
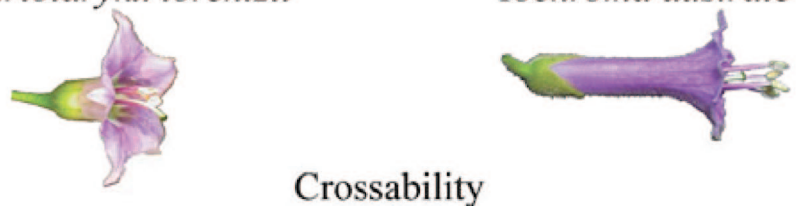

Crossability

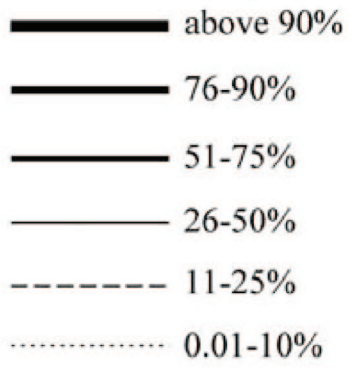

(no line) $0 \%$

Figure 2. Crossing relationships among Iochrominae. Crossability shown here is the ratio of the product of actual seed and seed viability between inter- and intraspecific crosses (Table 2). Flowers shown to scale. 


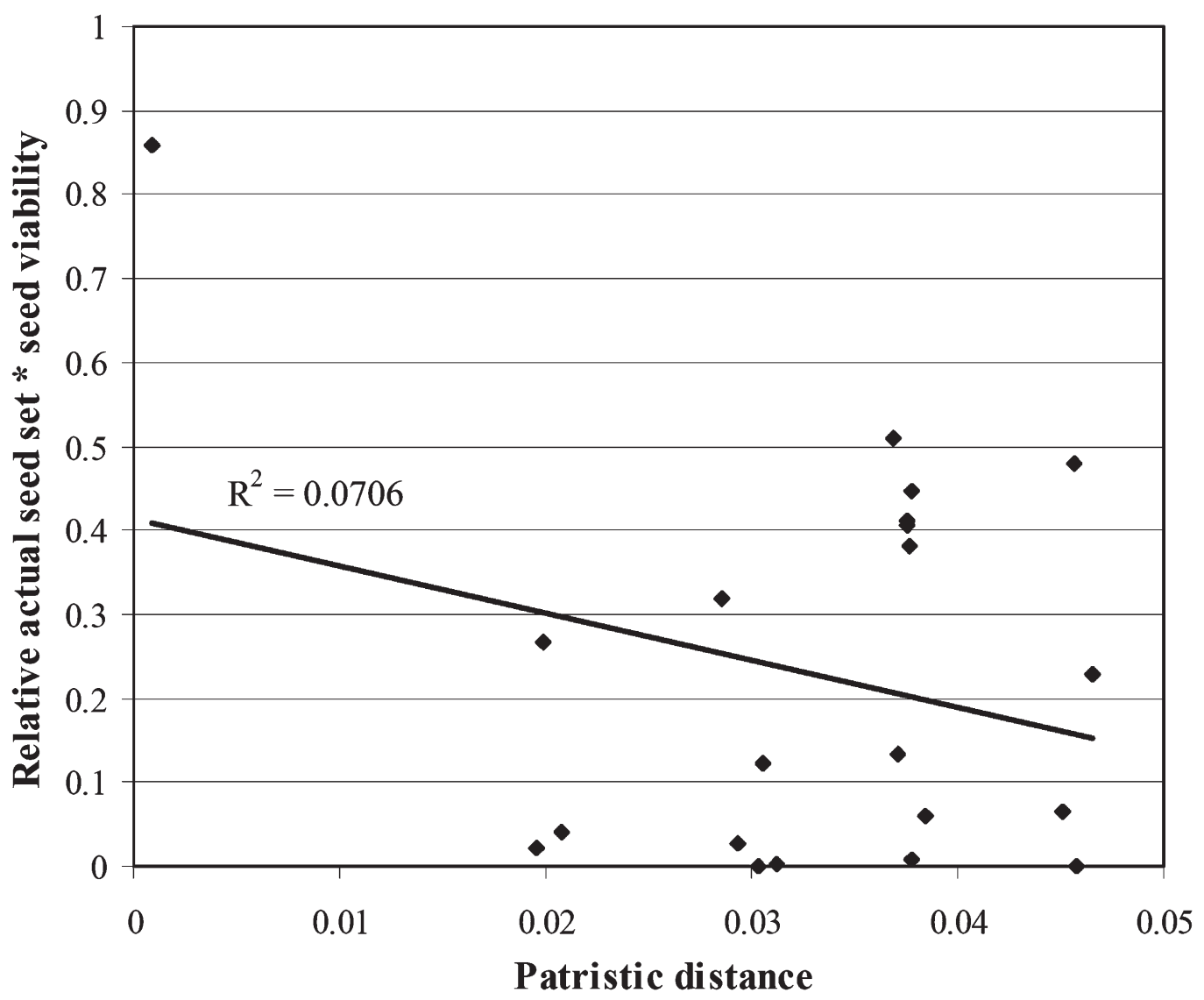

Figure 3. Crossability versus relatedness in Iochrominae. 